\title{
From a Realist Security Paradigm towards a Neoliberal Approach: Armed Conflict in Nagaland and Prospects for Pragmatic Resolution
}

Dominic K. Khanyo is an Assistant Professor at the Department of Political Science, Salesian College of Higher Education, Dimapur. His primary research interests include Theories of International Relations, Security and Strategic Studies, Political Theory and Political Philosophy.

\section{Abstract}

Armed conflict is one of the enduring and distinctive features in South Asian politics and security. The problem of armed conflict has posed a serious challenge for most of the nation states of the region. This paper seeks to examine the nature of the Naga conflict and its implications. The paper will also critically examine the efforts and measures undertaken by the Indian government towards conflict resolution in Nagaland over the past decades and will try to make a case as to why imbroglio persists despite efforts in resolving the conflict. This paper will make the case for a more nuanced and dynamic approach in understanding the nature of the conflict and its resolution. The paper will briefly look at the present paradigms or perspectives in understanding international politics in general and the issue of security in particular - Realist approach (Realism) and the Neo-liberal approach (Neoliberalism). The rationale of the effort is to broaden the horizon of our understanding of the dynamics of conflict and security which again is intrinsically linked or related with our perception towards evolving and devising prospective formulae or models of conflict resolution.

Key Words: Armed Conflict, Human Rights, Neorealism, Greater Nagaland, Neoleftist. 


\section{2/ Dominic K. Khanyo}

Salesian Journal of Humanities and Social Sciences, Vol. X, No. 1. (May 2019)

ISSN: 0976-1861 | DOI: 10.51818/SJHSS.10.2019.1-15 | Page: 01-15,

Section: Article

\section{Conceptual Definitions}

The term conflict can be defined as "incompatibility in the aim, goals or interests of two or more individuals, groups or other units." 1 According to Kenneth Boulding, "Conflict exists when any potential positions of two behaviour units are mutually incompatible." ${ }^{2} \mathrm{~A}$ classic understanding of conflict is that it is a dynamic phenomenon; one actor is reacting to what another actor is doing, which leads to further action. Quickly, the conflicts escalate. One sequence of events follows another, and it is difficult to decipher which party is more responsible for what happens. In popular understanding it is expressed as 'it takes two to conflict'. ${ }^{3}$

Conflict by itself is neither good nor bad. However, the manner in which conflict is handled determines whether it is constructive or destructive. ${ }^{4}$ Conflict is also defined as an incompatibility of goals or values between two or more parties in a relationship, combined with attempts to control each other and antagonistic feelings toward each other. ${ }^{5}$ The incompatibility or difference may exist in reality or may only be perceived by the parties involved. Nonetheless, the opposing actions and the hostile emotions are very real hallmarks of human conflict. There are various factors enhancing the conflict behaviour in parties. Misperception, impoverished communication, hostile attitudes, over sensitivity to difference, misjudgments, anarchic social situations and competitive spirit lead to distorted views that may intensify and perpetuate conflicts. Ho-won Jeong asserted that relative deprivation, dissatisfaction of basic needs, failure of organizational functions, asymmetric power relations and dominant social structures are the important components in the

\footnotetext{
${ }^{1}$ Roderick Ogley, Conflict Theory, ed. Lester Kurtz, Encyclopedia of violence, Peace and Conflict (London: Academic Press, 1999) Vol. 1, 402.

${ }^{2}$ Kenneth Boulding, Conflict and Defense: A General Theory (New York: Harper and Row Publishers, 1963), 4.

${ }^{3}$ Pooja Kataria, Conflict Resolution (New Delhi: Deep and Deep Publications, 2007), 12-13.

${ }^{4}$ Morton Deutsch and Peter T. Coleman, ed., The Handbook of Conflict Resolution: Theory and Practice (San Francisco: Jossey-Bass Publishers, 2000).

${ }^{5}$ Ron Fisher, The Social Psychology of Intergroup and International Conflict Resolution, Ronald Fisher, (New York: Springer-Verlag, 1990), 27.
} 
origin of conflict. Relative deprivation exists when people feel that their expectations of conditions for life have not been satisfied. ${ }^{6}$

Conflict can be defined as a disagreement through which the parties involved perceive a threat to their needs, interests or concerns. However, since the nature of Indo-Naga conflict takes the form of an armed conflict, it will be worthwhile to mention some of the definitions of armed conflict. Armed conflict can be termed as a political conflict in which armed combat involves the armed forces of at least one state or one or more armed factions seeking to gain control of all or part of the state. According to the United Nations Commission on Human Rights in a report titled International Legal Protection of Human Rights in Armed Conflict, published in 2011, while defining non-international armed conflict suggested that armed conflict refers to an armed confrontation between the armed forces of a State and non-governmental armed groups or between non-State armed groups.

\section{A Brief Historical Background of the Naga Conflict}

In the context of the conceptual definition discussed above let us try to analyse and understand the Naga conflict. Naga conflict can be categorized as ethnic armed conflict. However, before analyzing the nature of the contemporary Naga conflict, this section will take a brief look at the historical development of the conflict as any understanding of our current reality or phenomena in terms of both the practice and the theory of politics or international politics requires an understanding of the past with the ultimate aim of providing prognosis for the future. The genesis and rudimentary element of the armed conflict in the Naga areas could be traced back during the colonial period when the Nagas encountered the British expeditionary forces in the Naga hills in the early nineteenth century. Following the signing of the Treaty of Yandabo between the Burmese and the British in 1826, which ended the First AngloBurmese War (1824-26), the British were able to expand their political sphere of influence in the present Northeast region of India. That was beginning of the British occupation of the Naga areas. From

${ }^{6}$ Ho-won Jeong, Understanding Conflict and Conflict Analysis (London: Sage Publications, 2008), 36. 


\section{4 / Dominic K. Khanyo}

Salesian Journal of Humanities and Social Sciences, Vol. X, No. 1. (May 2019) ISSN: 0976-1861 | DOI: 10.51818/SJHSS.10.2019.1-15 | Page: 01-15,

Section: Article

then on the British slowly began to expand and exerted their control over the other Naga areas. ${ }^{7}$

During the occupation of the Naga hills one of the manifestations of the intentions and demands (aspirations) of the Nagas from the British came in the form of a memorandum submitted by the Naga Club to the Simon Commission in $1929 .{ }^{8}$ Another major development in the Nagas' struggle for self-determination movement was the formation of the Naga National Council (NNC) in 1946. Under the leadership of Angami Zapu Phizo, the NNC declared Nagaland an 'independent' state on August 14, 1947. As India became independent it was immediately posed with the Naga issue. In 1951, the NNC conducted a plebiscite wherein ninety nine per cent of the Nagas unanimously voted in favour of 'independence' from the Indian Union. The NNC rejected the Indian Constitution and boycotted the first Indian general election that was held in $1952 .{ }^{9}$ The Indian security forces were sent in the Naga areas in early 1950s to suppress the rebellion and subdue the Nagas' uprising. From then on armed conflict between the two sides ensued intermittently. In the late 1950s there were some efforts for resolving the conflict between the Indian government and the Nagas, most prominently represented by the Naga People's Convention which was formed in 1957. They eventually came up with a mutual agreement in the form of the Sixteen Point Agreement on 26 July 1960 and consequently

${ }^{7}$ The British used to carry out military expeditions in the Naga territory in order to establish a direct route for commuting between Assam and Manipur as well as to tackle the threat from the powerful Angami Naga warriors. The Battle of Khonoma during the 1870s only proved how strong resistance was put up by the Nagas against the imperialist forces. For more information, refer: AsosoYouno, The Rising Nagas: A Historical and Political Study, (New Delhi: Vikas, 1974). Aosenba, The Naga Resistance Movement: Prospects of Peace and Armed Conflict, (New Delhi: Regency Publications, 2000).

${ }^{8}$ Memorandum submitted to the Simon Commission on 10 January 1929 , cited in Aosenba, The Naga Resistance Movement: Prospects of Peace and Armed Conflict, (New Delhi: Regency Publications, 2000), 23.

${ }^{9}$ R.Vashum, Naga's Rights to Self-Determination, (New Delhi: Mittal Publication, 2000),80. Also see: Nirmal Nibedon, Nagaland: The Night of the Guerrillas, (New Delhi: Lancers, 1981), Tajenyuba Ao, The British Occupation of Naga Country, (Mokokchung: Naga Literary Society, 1993), 280-281. 
gave birth to the present state of Nagaland in December 1963. However this did not bring an end to the conflict.

Tensions and hostilities continued unabated in the Naga hills despite some efforts by the church leaders and other prominent personalities (Peace Mission, 1964). On November 11, 1975, the Indian government and a section of NNC leaders signed the Shillong Accord. However a group led by Thuingaleng Muivah, Isak Chisi Swu and SS Khaplang refused to accept and denounced the Shillong Accord, and formed the National Socialist Council of Nagaland in 1980. In 1988, the NSCN split into NSCN (IM) and NSCN (K) after a violent clash. ${ }^{10}$ The Government of India signed a ceasefire agreement with NSCN (IM) in August 1997. Subsequently, several rounds of talks between the two sides were held over the past two decades. On August 3, 2015, the government of India signed a peace accord with the key outfit, NSCN-IM which is also known as the 'Framework Agreement.' The Indian government has also signed ceasefire agreement with other Naga political groups. In April 2001, the Government of India entered into Cease Fire Agreement with the $\mathrm{NSCN}(\mathrm{K})$. The Indian government also signed a ceasefire agreement with the Working Group, the working committee comprising six Naga National Political Groups in November 2017.

\section{Critical Analysis of the Conflict resolution Approach}

The practice of controlling, colonizing and resolving conflicts adopted by the British colonial power is apparently evident even in India's attempt of managing and resolving 'internal' strife, particularly with respect to the Naga conflict. The divide and rule policy was also followed by the Indian government. The negotiating scope and accommodation of the demands of the Nagas were limited to piecemeal settlement. When there was tension in the hills, immediately following India's independence, the efforts undertaken by the government to resolve the issue was based on granting autonomy in governance and administration on incremental basis.

${ }^{10}$ M. Horam, Naga Insurgency: The Last Thirty Years, (New Delhi: Cosmo, 1988), 326. 


\section{6/ Dominic K. Khanyo}

Salesian Journal of Humanities and Social Sciences, Vol. X, No. 1. (May 2019) ISSN: 0976-1861 | DOI: 10.51818/SJHSS.10.2019.1-15 | Page: 01-15, Section: Article

The government negotiated with the Nagas and came up with a formula of forming an autonomous political entity known as Naga Hills Tuensang Autonomous Areas in 1957, which was administered along with the Naga Hills District within the state of Assam. When the Sixteen Point Agreement was signed in 1960 with the objective of bringing a solution to the Naga imbroglio, these two political entities were amalgamated into one entity which eventually became the present state of Nagaland in December 1963. This did not bring an end to the conflict as this arrangement was far from the demand of the Naga rebels. A large chunk of Naga areas and its populace were left out from the ambit of the arrangement which is the Nagaland.

Although, theoretically the provision for the integration of Naga inhabited areas was stipulated in the 16 point agreement, practically it was not implemented. Conflict ensued abated in the Naga areas even after the formation of Nagaland state. With a view to finding a solution there was another round of negotiation between the Indian government and the Naga rebels in between the mid-1960s and the early 1970s, which eventually resulted in the signing of the Shillong Accord in 1975. This again never brought hostilities in the Naga hills to an end.

Two critical observations can be surmised in the light of the above analysis. First, the Indian government was not really willing to address the core issue or concern of the Nagas which is the demand for self-determination and political independence. Rather the response of the Indian government lack prudence and maturity as it was evident from the fact that it was doling out some incremental based solution - from a district to an autonomous area and then to the granting of statehood - all of which could be considered as normal arrangement and permutations within the Indian federal polity. This is rather at odds with what actually the sensible approach should have been in as much as a complex issue requires some special and flexible resolution formula or matrix. Second, a large section of the Naga stakeholders were left out in the process of negotiation as well as in the final political arrangement (Nagaland) which represented only some of the Naga indigenous 
tribes. Whether this move was deliberate or sheer ignorance on the part of the Indian government is another point of contention. Given these two crucial factors coupled with the misperception which exists between the Indian government and the Naga rebels resulted in creating more tension and chasm between the two actors and thereby making the Naga conflict a protracted one.

\section{The Nature of the Naga Conflict}

The source of Naga conflict is primarily political in nature. However, other related aspects of conflict are also important in giving a more nuanced and a comprehensive understanding of Naga conflict. The socio-cultural element (ethnic dimension) is an important aspect of the conflict. The Nagas belong to the mongoloid ethnic stock that comprises of several tribes. Socio-culturally they have several distinctive practices and beliefs in common which makes them distinct from other related ethnic groups or races. The demand for an independent political set up is based on their sociocultural identity. Even without a rigid centralized (unitary) political authority they could have consolidated the numerous indigenous tribes under one centralized authority. However, historically the Nagas tended to thrive on a more loosely arranged federation of several indigenous tribes living in contiguous geographical area. In fact, each Naga village functions independently to great extent that it can arguably be considered as a proto-type republic or 'villagestate.' This aspect will have to be taken into consideration while examining or addressing the causes and nature as well as in finding a credible solution to the conflict by the Indian policy makers.

There is the economic perspective of the conflict too. Though many consider poor condition of economic development as one the causes of the conflict, there is another viewpoint which believes that the poor level of economic growth and development is the result (symptom) of the protracted nature of the conflict. However, it can also be argued that the typical characteristic of the Third World nations which is predominantly defined by poor economic condition had further exacerbated or aggravated the conflict. Lastly, there is the ideological and religious factors which can be overlapping but 


\section{8 / Dominic K. Khanyo}

Salesian Journal of Humanities and Social Sciences, Vol. X, No. 1. (May 2019) ISSN: 0976-1861 | DOI: 10.51818/SJHSS.10.2019.1-15 | Page: 01-15,

Section: Article

to some extent had a bearing on the nature of the Naga conflict. That the Nagas are predominantly Christians had not really helped the cause of national integration to some extent. The Naga political groups had often espoused the philosophy of 'Nagaland for Christ', which is rather at odds with the secular philosophy of the Indian State. No particular state in India openly declares its unflinching loyalty or faith to a particular deity or religion. Across all these aspects or dimensions of the conflict there are certainly differences in the perception between the leaders of Naga political groups and Indian State. Unless these factors or differences are addressed and understood, and more importantly there is mutual concession and reciprocity there can possibly be no long term solution to the Naga conflict.

\section{Theoretical Framework and Perspectives}

In consonance with highlighting the various perspectives in understanding the nature of the Naga conflict, there should also be an innovative or a revolutionary approach in adopting paradigms or theoretical groundings of international relations in finding a permanent resolution of the Naga conflict. At the time when India became independent in 1947, one of the dominant approaches of studying international relations (IR) was Realism. It is still one of the main approaches of IR even today. There are two main variants or strands of Realism - classical realism and Neorealism. Classical realism is a philosophical tradition that sees international politics as a perpetual struggle for power and resources in a world of scarcity. The state or political community, not the individual or economic class, is the primary unit of analysis in classical realism. The main function of the state is pursuit of national interest defined in terms of power and the struggle for survival and competition which is predominantly defined in terms of security or military aspect. The centrality of states and the pessimistic nature of humankind are some of its key assumptions. ${ }^{11}$

${ }^{11}$ Hans J Morganthau, Politics Among Nations: The Struggle for Power and Peace (New York: Alfred A. Knopf, 1948). 
On the other hand Neorealism or contemporary realism is an umbrella term that became popularly used in the post-1980 realist research program. Neorealism is also known as scientific realism or structural realism. ${ }^{12}$ In general, Neorealism emphasizes the influence of anarchy and uncertainty in the international system rather than the assumption of innate conflict or other innate characteristics of human nature. All variants of contemporary realism begin with the assumption that the international system - that is anarchy and the relative distribution of material power among the states that comprise the system - shape the broad parameters of international outcomes and the likely foreign policies of individual states. ${ }^{13}$

Since the time of India becoming a republic, its foreign policy principles were mostly informed and guided by ideals of Panchsheel and its adherence to the Non-aligned movement. However in practical terms, most of its interactions with its neighbours seemed to have been guided by realist principles. Even in dealing with internal security issues India's approach has been mostly in line with the traditional realist paradigm. Indian policy makers and planners will have to think out of the box in considering possible conflict resolution model for the Naga conflict. This paper seeks to argue that India should incorporate some ideals of Neo-liberal thinking in its approach to dealing with the Naga conflict.

Neoliberalism is also known as contemporary liberalism. Neoliberalism is a branch of liberalism ${ }^{14}$ In general, adherents of classical liberalism (also known as idealism) hold that the

\footnotetext{
${ }^{12}$ In 1979, Kenneth Waltz came up with his now famous work, Theory of International Politics, (1979) Reading, MA: Addison-Wesley. Many scholars (both self-described realists and non-realists) saw as a clean break with the classical realism of Hans Morgenthau, E.H. Carr, Arnold Wolfers, and Henry Kissinger.

${ }^{13}$ Also see, Waltz, Kenneth N., Man, State and War, (New York: Columbia University Press, 1959).

${ }^{14}$ Classical liberalism is a philosophical tradition that emphasizes the ability of human reason to create a world of peace and harmony. Liberalism presents a fundamentally optimistic view of human nature, in contrast to the pessimistic view presented by classical realism. Classical liberalism was largely an outgrowth of the Age of Enlightenment in late seventeenth and eighteenth century Western Europe.
} 


\section{0/ Dominic K. Khanyo}

Salesian Journal of Humanities and Social Sciences, Vol. X, No. 1. (May 2019) ISSN: 0976-1861 | DOI: 10.51818/SJHSS.10.2019.1-15 | Page: 01-15, Section: Article

international system tends strongly toward peace and cooperation among states that emphasizes the influence of democracy, free trade, and international institutions in promoting international cooperation and economic prosperity, rather than ability of human reason. Neoliberalism, which emerged in the aftermath of World War II, downplays the Realist's preoccupation with notion of struggle for survival in an anarchical world and the competition defined in security or military term, which is mostly a zero- sum game. $^{15}$

Neoliberalism can be further classified as a research program that encompasses several different strands of theories (subtheories) which include the democratic peace (or liberal peace) thesis, Neoliberal institutionalism, Complex interdependence theory and Economic liberalism (globalization theory). The paper seeks to give more emphasis to the validity and relevance of Complex Interdependence Theory with regard to the analysis of Naga conflict. ${ }^{16}$ Complex Interdependence theorists argue that trans-national relations, particularly economic ones, have increased since World War II. Conversely, the incidences of military force and power balancing among advanced industrialized states have decreased during the same period. Proponents of the theory argue that the decline of military force as a policy tool and the increase in economic and other forms of interdependence should increase the probability of cooperation among states. One can see the complex interdependence framework as an attempt to synthesize elements of realist and liberal thought.

\section{Neoliberal Approach to Naga Conflict}

Based on the theoretical approach and arguments presented above, this paper seeks to argue that in dealing with the Naga conflict

\footnotetext{
${ }^{15}$ For more on this approach see : Keohane, Robert O. and Nye, Joseph, Power and Interdependence: World Politics in Transition, (Boston: MA: Little Brown, 1977)

${ }^{16}$ Robert Keohane and Joseph S. Nye, Jr. coined the term 'complex interdependence' in reference to various, complex transnational connections (interdependencies) between states and societies. For more on this debate see: Keohane R, and Nye, Joseph S., Power and interdependence, (New York: Little Brown, 1977).
} 
it is time we move beyond the Realist's preoccupation with the pessimistic view of the human nature and international environment as well as seeing competition solely in terms of military security as the main objective or focus of the state to a more optimistic view of international politics enunciated by neoliberalism. The focus of the state should be on other non-military areas such as economy and trade. In fact, giving more emphasis on these aspects may help in reducing the animosity and misperception which is there between the two contending actors. Essentially what this entails is that the Indian government should begin to focus more on transgovernmental and transnational economic and trade ties involving Nagaland and its neighbours. Here this paper is making an assumption that the Indian government grants a quasi-sovereign status to the state of Nagaland including other Naga-inhabited areas as a single unique political entity co-existing and sharing powers with the Indian Union. The Indian government should also widen and intensify the network and areas of economic engagements or interactions. For instance, opening up trade ties with the South East Asian nations should be a positive step. For this to materialize the central government needs explore the potential areas for economic development and investment in Nagaland. The transnational and multinational companies should be allowed to participate and invest more in the region. As long as Indian government continues to look from the prism of Realism what they would perceive is mostly insecurity and mistrust in initiating such economic engagements and cooperation.

The effort on the part of the Indian government should be to de-emphasize the view that any major initiative or step in terms of allocating or devolving more responsibilities or power to the Nagas is seen as a potential for threat and insecurity. On the part of the Nagas, any bold move undertaken by the Indian government should be reciprocated with optimism and should not be looked at with suspicion and mistrust. The interactions between the two sides should not be seen as a zero-sum game manner. Both sides should rather be open to more prospective mutual interactions and engagements across various areas and sectors which will be 


\section{2/ Dominic K. Khanyo}

Salesian Journal of Humanities and Social Sciences, Vol. X, No. 1. (May 2019) ISSN: 0976-1861 | DOI: 10.51818/SJHSS.10.2019.1-15 | Page: 01-15, Section: Article

advantageous for both the parties and which will promote peace and prosperity in the South Asian Region.

\section{Re-thinking on the Westphalian Model}

In order to make the above analysis less abstract and also to provide a prognosis, the paper intends to suggest some innovative measures keeping in mind the prospective models for conflict resolution. There is a need to re-visit the notion of territorial state system. The Westphalian model of the 'Sovereign State System' adopted and practiced today by the nation-states across the international system emerged a result or by-product of the Treaty of Westphalia of $1648 .{ }^{17}$ The treaty introduced the principle of national sovereignty and placed the states of Europe on an equal legal footing. It also established the norms of territorial integrity and non-interference in the domestic affairs of other states.

Though the Westphalian model is widely practiced, questions regarding its effectiveness or utility in some parts of the world in contemporary international politics are probably open for debate. The experience of 'implanting' the Westphalian model in some of the Third World nation-states such Iraq, Libya and Syria in the Middle-East, Afghanistan and Myanmar in Asia and in some African states is far from satisfactory. Also, given the phenomenal changes and transformation in international politics, it should be worth re-examining the efficacy and validity of this model. What this paper seeks to suggest is not the discarding of Westphalian arrangement entirely but to come up with a modified version or model by retaining the best principles of the Westphalian model and incorporating some changes, keeping in mind the sociopolitical, economic and historical conditions or distinctiveness of the region in which the state is located. I presumed that the notion of 'shared-sovereignty' or 'special federal relationship' which are often paraded in the media in relation with the Indo-Naga peace

\footnotetext{
${ }^{17}$ It is also known as Peace of Westphalia 1648) marked the end of the Thirty Years' War in Europe. See: Richard A Falk, "The Interplay of Westphalia and Charter Conceptions of International Legal Order", in The Future of the International Legal Order, Vol. 1 Trends and Patterns, ed . Cyril E. Black and Richard A Falk, (Princeton, NJ: Princeton University Press, 1969), 32-72.
} 
talks could be indications of how leaders on both sides are beginning to explore the possibilities of having a re-look at this traditional understanding of the Sovereign State System or concept.

The challenge for every policy planner or analyst should be to explore or find ways to improvise upon the existing system. The present model of the Sovereign State System can be modified in such a way to accommodate the crucial demands or grant of special rights and autonomy within a state. In the context of Indo-Naga peace dialogue there can be an arrangement where the Central government grants substantial autonomy to a particular state, for instance to an entity which comprises all the Naga-inhabited areas (Greater Nagaland). The arrangement would be such that the constitution of India allows the existence of such an entity along with other states. More importantly the provision for granting such a unique status should be non-amendable by the Indian Parliament. What should the government or 'Parliament' of the new political entity or 'Greater Nagaland' be willing to concede? As a quid pro quo the government of the newly created entity should be willing accept an arrangement where in areas related to defence and foreign policy it should consult the Indian government or in extreme cases should require the consent of the Indian Parliament.

Another measure which can be considered and is also correlated with the points discussed above is the re-examination or revising the notion of federalism. ${ }^{18}$ The conservative understanding of Federalism or federal structure of the Indian polity should be re-visited. The division of power which is best exemplified by the provision of Union List, State List and the Concurrent List clearly delineates the centre-state relations in India. If at all there can be some modifications in our federal set up. Technically it can be done in the allocation and distribution of the legislative items/subjects in the concerned lists. Structurally the federal arrangements remains

\footnotetext{
${ }^{18}$ Federalism is a method of government that allows two or more entities to share control over the same geographic region. Federalism is a system of government in which there is division of power between a central government and regional or state governments. In other words, Federalism is the sharing of power between national and state governments.
} 


\section{4 / Dominic K. Khanyo}

Salesian Journal of Humanities and Social Sciences, Vol. X, No. 1. (May 2019) ISSN: 0976-1861 | DOI: 10.51818/SJHSS.10.2019.1-15 | Page: 01-15,

Section: Article

unchanged, the centre and its units(the states). The only visible modification can be in qualitative terms, that is, to enhance the power and allocate more subjects in favor of the unit/state. This formula can be incorporated in the negotiation between the Indian government and the Naga leaders. From the Indian perspective, it can be a good bargain because the scope of the modification is still within the framework of its constitution. On the other hand, for the Naga political leaders this could seem like a deviation from their original demand which is outside the ambit of the Indian Constitution. The one possible way out of this dilemma could be to introduce a preamble-like 'clause' which shall contain all the special and exclusive provisions for the Nagas and it should not be amendable. The provisions within the clause should be able to suggest explicitly that it is a 'joint' preamble and that does not fall exclusively within the Indian constitution.

\section{Implications of the Naga Conflict}

First and foremost, the resolution of the conflict is in the interest of both the Indian government and the Nagas. The protracted nature of the conflict can only have negative impact for both the parties. It hampers the development of the region. India cannot ignore the imperative of settling this long standing issue given its larger regional and global ambitions as rising power in South Asia. Therefore, the neoliberal approach in understanding and conducting international politics become ever more prudent for Indian policy makers. India needs a vibrant economy and more footprints in the global as well as regional markets. Nagaland is at a very strategic point in relation with the adjoining neighbors such as Myanmar and the rest of the South East Asian nations as well as to some extent, with China. Naga areas can be considered as a gateway to the South-East Asian corridor. The proposed 'Act East' policy of the Indian government makes much sense in this context. So, in general, the Northeastern region cannot be a conflict zone if India aspires to be a great power. India's future grand strategy of achieving such a status heavily depends on its economic development and relatively peaceful state 
making it an attractive destination from the market point of view. There is also another implication of the Naga conflict. It has bearing on the regional security of South Asia. The armed rebels or militants in the region find their safe 'havens' and the place for their strategic and logistical supplies in Myanmar and Bangladesh. This kind of network and activities make the region more volatile from security point of view.

\section{Conclusion}

This paper attempted to understand Naga conflict from a theoretical perspective of international politics based on a given historical context which was highlighted briefly. It analysed the nature of the conflict which suggested multiple dimensions of the nature and sources of the conflict. Though primarily political in nature (ethnic armed conflict) other aspects such as socio-cultural, religious and ideology also play a crucial role. The paper also presented the realist framework of understanding politics being the dominant approach even today and for conflict resolution model. It argued for a shift from a realist paradigm to a new one, neo-liberal approach which focuses more on non-traditional security areas. The focus of the state's interaction should be more on economic, trade and other areas of complex inter-dependence. It is time for India to take a giant leap of faith and undertake a dramatic shift in its approach to dealing and resolving conflicts. It may be time that we go beyond the traditional sovereign state system model as the mainstay and foundation of international politics. It is prudent on the part of the policy makers to address the issue holistically and maturely rely on credible insights so as to find a viable permanent solution to one of the longest standing conflicts in South Asia. 